\title{
KONTRIBUSI USAHATANI BUNGA KRISAN TERHADAP PENDAPATAN RUMAH TANGGA PETANI DI KECAMATAN BANDUNGAN KABUPATEN SEMARANG
}

\author{
A. Maghfira, A. Setiadi, dan T. Ekowati \\ Program Studi S1 Agribisnis Fakultas Peternakan dan Pertanian \\ Universitas Diponegoro, Semarang 50275 \\ Email: astari.maghfira@gmail.com \\ Diterima 7 Februari 2017, disetujui 7 Maret 2017
}

\begin{abstract}
ABSTRAK
Usahatani umumnya dijadikan sebagai sumber pendapatan utama rumah tangga tani. Namun proporsi pendapatan usahatani dalam pendapatan total rumah tangga tani mengalami penurunan. Penelitian ini bertujuan untuk mengetahui kontribusi usahatani bunga krisan pada pendapatan rumah tangga petani. Metode penelitian ini memakai metode survai. Penelitian ini telah dilakkukan pada 40 responden rumah tangga petani bunga krisan di Desa Duren dan Desa Kenteng secara snowball sampling. Hasil penelitian menunjukkan bahwa 1) Pendapatan bunga krisan satu musim tanam sebesar Rp 8.311.492. 2) Profitabilitas usahatani bunga krisan bernilai $86,03 \%$. 3) Terdapat perbedaan rata-rata pendapatan bunga krisan dengan rata-rata pendapatan lain diluar usahatani bunga krisan dalam total pendapatan rumah tangga tani. 4) Kontribusi pendapatan usahatani bunga krisan terhadap pendapatan total rumah tangga petani yaitu sebesar $59,34 \%$.
\end{abstract}

Kata Kunci: bunga krisan, kontribusi, pendapatan. usahatani, rumah tangga tani

\begin{abstract}
Farm enterprise are generally the first source of income for farm household. But the proportion of farm income in total farm household income had decreased. The study aimed to determine the contribution of chrysanthemums farm to the household farm income. The method was used in this study was survey method. The study have been done on 40 chrysanthemum farm household at Duren Village and Kenteng Village in snowball sampling. The results showed that 1) chrysanthemums farm incomes amounted to IDR 8,311,492.2) Profitability chrysanthemum farm is worth $86,03 \%$. 3) There are differences in the average income of the chrysanthemum farm with the average income from outside income from chrysanthemums farm in total farm household income. 3) The average contribution chrysanthemum farm income to the total income of farm households amounted to $59,34 \%$.
\end{abstract}

Keywords: chrysanthemums, contribution, income, farming, farm households

\section{PENDAHULUAN}

Pengelolaan usahatani di Indonesia pada umumnya dilakukan oleh keluarga di pedesaan secara turun-temurun sehingga dijadikan sumber utama pendapatan masyarakat. Namun bila dibandingkan dengan hasil penelitian Barokah et al. (2012) 
menunjukkan selama tahun 1998 - 2010 proporsi pendapatan usahatani berkurang 8,30 $\%$ (dari $42 \%$ menjadi 33,7 \%) dan proporsi pendapatan luar usahatani meningkat 10,30\% (dari $54 \%$ menjadi 64,30 \%). Alhasil, pekerjaan di sektor pertanian menjadi tidak menggiurkan.

Sektor pertanian butuh komoditas yang memiliki nilai jual dan berdaya saing untuk meningkatkan daya tarik masyarakat sebagai salah satu sektor ekonomi. Bunga krisan (Chrysanthemum Grandiflorum) sebagai bunga potong sangat digemari karena keindahannya baik dalam bentuk, warna serta kesegaran bunga cukup lama. Bunga krisan digunakan untuk bahan dekorasi ruangan pada acara pesta. Salah satu sentra produksi bunga krisan di Kabupaten Semarang terletak di Kecamatan Bandungan yang ditunjukan dari perkembangan luas panen bunga krisan sebesar $1.524 .800 \mathrm{~m}^{2}$ yang menghasilkan 96.748.560 tangkai (Badan Pusat Statistik Kabupaten Semarang, 2015).

Tujuan dari penelitian adalah 1) Menganalisis pendapatan usahatani bunga krisan di Kecamatan Bandungan. 2) Mengetahui profitabilitas usahatani bunga krisan di Kecamatan Bandungan. 3) Membandingkan pendapatan usahatani bunga krisan dan pendapatan luar usahatani bunga krisan dalam rumah tangga tani di Kecamatan Bandungan. 4) Mengetahui besarnya sumbangan pendapatan usahatani bunga krisan terhadap pendapatan total rumah tanga petani bungan krisan Kecamatan Bandungan. Manfaat penelitian ini diharapkan dapa tmenjadi pertimbangan bagi pihak yang berkaitan dalam pengembangan usahatani bunga krisan pada umumnya serta sebagai bahan referensi untuk penelitian selanjutnya.

\section{METODE PENELITIAN}

Penelitian ini dilaksanakan pada bulan Desember 2016 di Desa Kenteng dan Desa Duren, Kecamatan Bandungan, Kabupaten Semarang. Pemilihan daerah dilakukan dengan sengaja (purposive) dengan kriteria merupakan penghasil bunga krisan terbesar di
Kabupaten Semarang. Metode purposive adalah teknik penentuan sampel dengan petimbangan tertentu (Sugiyono, 2008).

Sampel yang dipilih pada penelitian ini adalah rumah tangga petani bunga krisan dengan syarat memiliki pendapatan dari usaha atau profesi lain diluar usahatani bunga krisan. Teknik pengambilan sampel menggunakan snowball sampling. Alasan menggunakan snowball sampling karena minimnya informasi mengenai jumlah rumah tangga petani bunga krisan serta syarat sampel yang dikehendaki. Snowball sampling adalah teknik penentuan sampel yang mulamula jumlahnya kecil, kemudian sampel ini memilih rekannya yang sekiranya memiliki karakteristik yang sama dengannya, sehingga jumlah sampel semakin banyak ibarat bola salju yang terus menggelinding semakin lama semakin besar (Sugiyono, 2008). Jumlah sampel yang diambil sebanyak 40 rumah tangga petani bunga krisan. Sampel pertama ditujukan kepada ketua kelompok tani bunga krisan di Desa Duren dan Desa Kenteng lalu direkomendasikan rekannya yang berada di desa yang memenuhi syarat. Menurut Nurdiani (2008) teknik snowball sampling, jumlah orang atau responden awal yang diperlukan adalah 2-12 orang kemudian dari responden awal tersebut dapat diperoleh 1030 untuk ukuran sampel sedang (medium) dan $>30$ untuk ukuran sampel besar.

Hipotesis penelitian ditentukan sebagai berikut:

1.Pendapatan usahatani bunga krisan satu musim tanam lebih besar dari Upah Minimum Kabupaten Semarang sebulan yaitu $\mathrm{Rp}$ 1.745.000.

2.Usahatani bunga krisan menguntungkan

3.Ada perbedaan antara rata-rata pendapatan usahatani bunga krisan dan pendapatan luar usahatani bunga krisan dalam pendapatan total rumah tangga tani

4.Pendapatan usahatani bunga krisan memiliki kontribusi lebih dari 50\% terhadap pendapatan rumah tangga tani

Biaya dalam usahatani atau total cost (TC) dirumuskan Soekartawi (2002) sebagai berikut: 


$$
\mathrm{TC}=\sum \mathrm{X} . \mathrm{Px}
$$

Penerimaan usahatani dirumuskan Soekartawi (2002) sebagai berikut:

$$
\mathrm{TR}=\sum \mathrm{Y} \text {. Py. }
$$

Pendapatan (Pd) dirumuskan Soekartawi (2002) sebagai berikut:

$$
\mathrm{Pd}=\text { Total Revenue (TR)-Total Cost (TC) }
$$

Hipotesis 1 diuji dengan uji t satu sampel yang dibandingkan dengan Upah Minimum Kabupaten Semarang selama sebulan yaitu Rp 1.745.000 per bulannya.

Profitabilitas adalah perbandingan antara penerimaan dan biaya yang berkaitan dengan usahatani yang dinyatakan dalam rumus berikut:

Profitabilitas $=\frac{\text { Pendapatan Bersih }(\mathrm{Rp})}{\text { Biaya }(\mathrm{Rp})} \times 100 \%$

Namun pada penelitian ini petani responden tidak dikenakan pajak atas penghasilannya. Selanjutnya hipotesis 2 diuji dengan uji t satu sampel yang dibandingkan dengan suku bunga bank BRI 4 bulan yaitu $1,67 \%$.

Pendapatan rumah tangga di perdesaan berasal dari berbagai kegiatan. Seperti pada rumus dalam Rahim dan Diah (2008) sebagai berikut:

Total Pendapatan Rumah Tangga $\left(\mathrm{Y}_{\text {tot }}\right)=$

$$
\mathrm{Y}_{1}+\mathrm{Y}_{2}+\mathrm{Y} 3+\mathrm{Y}_{\mathrm{n}}
$$

Hipotesis 3 diuji dengan paired sample t-test untuk mengidentifikasi perbedaan pendapatan usahatani bunga krisan dengan pendapatan diluar usahatani bunga krisan yang dijalankan anggota rumah tangga tani bunga krisan.

Kontribusi pendapatan adalah besarnya sumbangan pendapatan terhadap pendapatan total rumah tangga petani yang dinyatakan dalam persen (\%) dalam Rahim dan Diah (2008):

Kontribusi Pendapatan $(\%)=\frac{\text { Pendapatan UT Bunga Krisan }}{\text { Pendapatan lain }} \times 100$
Hipotesis 4 diuji dengan uji t satu sampel dengan membandingkan kriteria minimal kontribusi yaitu sebanyak 50\% terhadap pendapatan rumah tangga tani.

\section{HASIL DAN PEMBAHASAN}

\section{Karakteristik Rumah Tangga Petani Responden}

Karakteristik rumah tangga petani responden pada usahatani bunga krisan di Kecamatan Bandungan dapat dilihat pada Tabel 1. Tabel 1. dapat dilihat bahwa rata-rata umur petani responden berada pada umur produktif yaitu 44 tahun. Pada usia ini petani mampu mengelola usahataninya serta dapat mengembangkan potensi yang mereka miliki. Menurut Sutarto (2005) seseorang yang berusia tiga puluh lima tahun ke atas untuk lebih memantapkan dirinya dalam bekerja, berkenaan dengan semakin tingginya biaya hidup yang perlu dikeluarkan.

Jumlah rata-rata anggota keluarga responden adalah 4 orang. Rumah tangga petani responden sebagian besar berasal dari keluarga muda. Menurut Badan Pusat Statistik (2013) jumlah anggota rumah tangga adalah seluruh jumlah anggota rumah tangga yang tinggal dan makan dari satu dapur.

Rata-rata pengalaman petani dalam usahatani berkisar 5 tahun. Bunga krisan memang masih tergolong baru ramai ditanam oleh petani sejak 10 tahun yang lalu dan merupakan pengalaman baru bagi petani. Sutarto (2005) mengatakan bahwa pengalaman dapat membentuk sikap sebagai proses semakin meningkatnya pengetahuan yang dimiliki petani.

\section{Pendapatan dan Profitabilitas Usahatani Bunga Krisan}

Menghitung pendapatan dilakukan untuk menentukan nilai yang diperoleh petani dari kegiatan berusahatani. Rata-rata pendapatan responden petani dirincikan pada Tabel 2.

Penyusutan dihitung sebagai biaya yang harus dikeluarkan petani terhadap green house dan alat pertanian seperti cangkul, tangki pestisida, gunting panen dan pompa 
Tabel 1. Karakteristik Rumah Tangga Petani Responden Pada Usahatani Bunga Krisan Di Kecamatan Bandungan

\begin{tabular}{|c|c|c|}
\hline Uraian & $\begin{array}{l}\text { Jumlah } \\
\text { (Orang) }\end{array}$ & $\begin{array}{c}\text { Persentase } \\
(\%)\end{array}$ \\
\hline \multicolumn{3}{|c|}{ Rata-rata umur petani (tahun) } \\
\hline$-28-35$ & 10 & 24,39 \\
\hline$-36-45$ & 17 & 43,90 \\
\hline$-46-55$ & 11 & 26,82 \\
\hline$->55$ & 2 & 4,89 \\
\hline \multicolumn{3}{|c|}{$\begin{array}{l}\text { Rata-rata jumlah anggota rumah tangga } \\
\text { (orang) }\end{array}$} \\
\hline-3 & 16 & 39,02 \\
\hline-4 & 18 & 43,90 \\
\hline-5 & 7 & 17,08 \\
\hline \multicolumn{3}{|l|}{ Rata-rata luas lahan $\left(\mathrm{m}^{2}\right)$} \\
\hline$-350-600$ & 10 & 24,30 \\
\hline$-601-1000$ & 11 & 27,50 \\
\hline$-1001-1500$ & 12 & 30,00 \\
\hline$->1.500$ & 7 & 17,50 \\
\hline \multicolumn{3}{|c|}{ Rata-rata pengalaman usahatani (tahun) } \\
\hline$-2-5$ & 23 & 57,50 \\
\hline$-6-10$ & 9 & 22,50 \\
\hline$->10$ & 8 & 20,00 \\
\hline Jumlah petani responden & 40 & 100,00 \\
\hline
\end{tabular}

Sumber : Data Primer, 2016.

Tabel 2. Rata-rata Pendapatan dan Profitabilitas Usahatani Bunga Krisan per Musim Tanam

\begin{tabular}{lcc} 
& \multicolumn{2}{c}{ Biaya Usahatani } \\
\cline { 2 - 3 } Rincian Biaya & Jumlah & Persentase \\
\hline A.Penerimaan & -- Rp -- & $--\%--$ \\
B.Biaya Tetap & 18.914 .863 & \\
- Penyusutan greenhouse dan alat & 1.754 .542 & 16,55 \\
$\quad$ pertanian & & \\
- Pajak PBB & 12.741 & 0.12 \\
- Sewa lahan & 588.088 & 5.55 \\
- Listrik & 203.388 & 1,92 \\
C. Biaya Variabel & & \\
- Bibit & 3.794 .800 & 35,79 \\
- Pupuk & 1.628 .375 & 15,36 \\
- Pestisida & 501.775 & 4,73 \\
- Tenaga kerja & 1.465 .138 & 13,82 \\
- Pasca panen & 654.525 & 6,17 \\
D.Total Biaya & 10.603 .371 & 100,00 \\
\hline E. Pendapatan & 8.311 .492 & 86,03 \\
\hline F. Profitabilitas & &
\end{tabular}

Sumber: Data Primer, 2016. 
air. Hal ini sesuai dengan pendapat Mubyarto (1991) menyatakan bahwa modal adalah barang atau uang yang bersama-sama faktor lain menghasilkan barang-barang yaitu berupa hasil pertanian. Biaya listrik yang dihitung merupakan biaya listrik yang berasal hanya dari green house dan mutlak dibutuhkan oleh bunga krisan karena merupakan tanaman yang membutuhkan cahaya tambahan. Hal ini sesuai dengan Budiarto et al. (2006) yang mengatakan bahwa tanaman krisan mengalami dua periode pertumbuhan yaitu pertumbuhan periode hari panjang (vegetatif) dan periode hari pendek (generatif).

Pemupukan dilakukan 3-4 kali dalam satu kali musim tanam. Pemupukan pertama digunakan pupuk kandang. Hal ini sesuai dengan pendapat dalam Zainudin (2007) bahwa pupuk organik dapat mengurangi serangan hama karena meningkatnya jenis dan populasi predator maupun mikroba antagonis yang sangat bermanfaat bagi keberhasilan penerapan sistem pertanian organik. Adapun biaya tenaga kerja petani menggunakan tenaga kerja dalam keluarga maupun tenaga kerja luar meliputi proses pengolahan tanah, penanaman, penyiangan, pemupukan, pengendalian Hama dan Penyakit (HPT), panen dan pasca panen. Petani biasa menggunakan tenaga kerja luar pria untuk mengolah tanah sedangkan untuk pekerjaan ringan seperti pasca panen petani memilih menggunakan tenaga kerja dalam keluarga atau luar wanita. Hal ini sesuai dengan pendapat Tegegne et al. (2001) yang menyatakan bahwa biaya input teknologi yang padat modal bisa diganti oleh tenaga kerja keluarga dan pada saat yang sama dapat melindungi lingkungan. Biaya pasca panen yang dimaksud adalah beban yang dikeluarkan petani untuk menjual hasil panennya. Hal ini sesuai dengan pendapat Tjiptono (1999) menyatakan bahwa pemberian kemasan pada produk memiliki fungsi, antara lain (a) pelindung isi (protection); (b) memberi daya tarik (promotion) berupa warna, bentuk, dan desain dan (c) memudahkan proses distribusi.
Produksi bunga krisan merupakan faktor penentu besarnya penerimaan petani tergantung jenis warna, kuantitas dan kualitas dari bunga krisan yang dihasilkan. Kelas A adalah kelas bunga yang memiliki harga tertinggi. Pada umumnya petani responden memproduksi bunga krisan kelas A dan kelas B. Petani yang rajin melakukan perawatan dengan benar tidak akan kesusahan untuk memproduksi bunga krisan kelas A. Pada penelitian ini bunga krisan yang ditanam petani bunga krisan ada 5 jenis yaitu Puspita Nusantara, Sena, Remix, Bakardi, Lollipop dan Lolired. Bunga yang menghasilkan penerimaan terbanyak jatuh pada bunga sena. Petani bunga krisan menanam bunga sena karena bunga tersebut banyak digemari masyarakat.

Hipotesis pertama diuji untuk mengetahui pendapatan usahatani setara dengan Upah Minimum Regional (UMR) Kabupaten Semarang dengan uji one sample t-test. Pengujian one sample t-test dibandingkan dengan Upah Minimum Kabupaten Semarang diperoleh nilai signifikansi sebesar $0,049<0,05$. Artinya pendapatan usahatani bunga krisan satu musim tanam sama dengan UMK Kabupaten Semarang selama 4 bulan yaitu Rp 6.980 .000 atau sebesar Rp 1.745.000 per bulannya (H0 ditolak, $\mathrm{H} 1$ diterima). Ini berarti petani bunga krisan masih mendapatkan sejumlah uang yang lebih dari UMK Semarang.

Berdasarkan Tabel 2. dapat diketahui bahwa profitabilitas usahatani bunga krisan adalah sebesar $86,03 \%$. Artinya usahatani bunga krisan dapat dikatakan untung. Artinya usahatani bunga krisan dapat menghasilkan pendapatan karena setiap rupiah biaya yang dikeluarkan dapat menghasilkan laba sebesar 0,86 kali biayanya. Hipotesis kedua diuji untuk mengetahui pendapatan usahatani setara dengan suku bunga bank BRI selama 4 bulan yaitu $1,67 \%$ dengan uji one sample $t$ test. Berdasarkan one sample t-test yang dibandingkan dengan suku bunga bank BRI selama 4 bulan yaitu $1,67 \%$ diperoleh nilai signifikansi sebesar $0,00<0,05$ (taraf kritis). Artinya usahatani bunga krisan 
menguntungkan (H0 ditolak, $\mathrm{H} 1$ diterima). Ini berarti usahatani bunga krisan dapat dijadikan pilihan usaha yang dapat dijalankan secara berkelanjutan karena terbukti mampu menghasilkan profit yang menguntungkan. Hal ini sesuai dengan Rahim dan Hastuti (2008) yang mengatakan bahwa usahatani dikatakan untung bila setiap biaya yang dikeluarkan untuk usahatani menghasilkan keuntungan yang lebih besar dari biaya yang dikeluarkan.

\section{Pendapatan Rumah Tangga di Luar Usahatani Bunga Krisan}

Meskipun keseluruhan petani responden menggantungkan hidupnya pada usahatani bunga krisan, namun ada pula anggota rumah tangga yang berusaha atau bekerja di luar usahatani yang akan dirincikan pada Tabel 3 .

Tabel 3. Rata-rata Pendapatan Dari Luar Usahatani Bunga Krisan Per Satu Periode Musim Tanam Bunga Krisan di Kecamatan Bandungan Kabupaten Semarang.

\begin{tabular}{lrr}
\hline \multicolumn{1}{c}{ Uraian } & $\begin{array}{c}\text { Pendapatan Luar } \\
\text { Usahatani Bunga } \\
\text { Krisan }\end{array}$ \\
& \multicolumn{1}{c}{ Rp -- } & $--\%--$ \\
Usahatani lain & 1.326 .896 & 23,35 \\
Pengepul & 832.000 & 14,64 \\
Pedagang & 1.010 .000 & 17,78 \\
PNS & 380.000 & 6,69 \\
Karyawan Kantor & 870.000 & 15,31 \\
Guru & 380.000 & 6,69 \\
Buruh & 198.000 & 3,48 \\
Lainnya & 685.000 & 12,06 \\
\hline Rata-rata & 5.681 .896 & 100,00 \\
\hline
\end{tabular}

Sumber: Data Primer, 2016.

Pendapatan dari luar usahatani berasal dari 8 sumber pendapatan. Perbedaan jenis pekerjaan tersebut tergantung pada kesempatan, kemampuan dan kemauan yang dimiliki petani. Hal ini sesuai dengan pendapat Nurmanaf (2006) yang mengatakan bahwa tingkat keragaman tersebut dipengaruhi oleh penguasaan faktor produksi dan aset rumah tangga. Hipotesis kedua diuji untuk mengetahui perbedaan antara pendapatan usahatani dan pendapatan diluar usahatani bunga krisan yang diuji dengan paired sample t-test. Sebelum masuk ke uji tersebut, perlu dilakukan uji normalitas dengan Kolmogorov-Smirnov diperoleh nilai pada pendapatan usahatani bunga krisan diperoleh signifikansi $0,60>0,05$. Artinya data berdistribusi normal. Nilai signifikansi dari paired sample t-test adalah $0,00<0,05$. Artinya terdapat perbedaan antara rata-rata pendapatan bunga krisan dan rata-rata pendapatan luar krisan (H0 ditolak, H1 diterima). Ini menandakan bahwa pendapatan yang diperoleh dari usahatani bunga krisan dan diluar usahatani bunga krisan memiliki perbedaan yang nyata. Hal ini sesuai dengan Agustian dan Ilham (2008) yang mengatakan bahwa struktur pendapatan di perdesaan telah mengalami perubahan, namun sektor pertanian masih merupakan andalan utama pendapatan rumah tangga.

\section{Kontribusi Pendapatan Usahatani Bunga Krisan}

Kontribusi pendapatan usahatani bunga krisan pada total pendapatan rumah tangga tani dapat dilihat pada Tabel 4.

Tabel 4. Kontribusi Pendapatan Usahatani Bunga Krisan Pada Total Pendapatan Rumah Tangga Tani

\begin{tabular}{lcc}
\hline \multicolumn{1}{c}{ Uraian } & Pendapatan & Kontribusi \\
\hline Usahatani & $--\mathrm{Rp}--$ & $--\%--$ \\
Bunga & 8.311 .492 & 59,34 \\
Krisan & & \\
Luar & 5.681 .896 & 40,66 \\
Usahatani & & \\
Bunga Krisan & & \\
\hline Total & 13.993 .388 & 100,00 \\
\hline
\end{tabular}

Sumber: Data Primer, 2016

Usahatani bunga krisan memberikan kontribusi pendapatan sebesar 59,34\% terhadap pendapatan total rumah tangga petani. Artinya, kontribusi usahatani bunga krisan dikategorikan tinggi. Patty (2010) mengatakan bahwa range kontribusi usahatani diantara $50 \% \quad-75 \%$ terhadap 
pendapatan total rumah tangga tani digolongkan sebagai kontribusi tinggi. Tingginya nilai kontribusi menunjukkan bahwa pendapatan mendominasi pendapatan sehingga petani masih mengandalkan usahatani bunga krisan sebagai sumber pendapatan rumah tangga petani.

Berdasarkan uji one sample t-test yang terdapat pada diperoleh nilai signifikansi sebesar 0,001<0,05 (taraf kritis). Artinya kontribusi usahatani bunga krisan memberikan sumbangan kontribusi lebih dari $50 \%$ terhadap pendapatan total rumah tangga tani (H0 ditolak, H1 diterima). Ini menunjukan pertanda baik bahwa usahatani memberikan kontribusi nyata terhadap rumah tangga pertanian tidak seperti penelitian sebelumnya yang dilakukan oleh USDA (2004) di Amerika yang menyebutkan bahwa 85\%-95\% dari pendapatan rumah tangga pertanian datang dari sumber off-farm.

\section{KESIMPULAN}

Berdasarkan uraian pada hasil dan pembahasan, maka dapat dikemukakan kesimpulan sebagai berikut:

1. Pendapatan bunga krisan selama satu musim tanam sebesar Rp 8.311.492 lebih tinggi dibandingkan dengan UMK Kabupaten Semarang yaitu Rp 1.745.000 per bulannya.

2. Profitabilitas usahatani bunga krisan memiliki nilai sebesar $86,03 \%$. Nilai ini lebih tinggi dibandingkan suku bunga bank selama 4 bulan yaitu $1,67 \%$.

3. Terdapat perbedaan rata-rata pendapatan bunga krisan dengan rata-rata pendapatan lain diluar usahatani bunga krisan dalam total pendapatan rumah tangga tani. Pendapatan bunga krisan per musim tanam adalah Rp 8.311.492 sedangkan pendapatan diluar usahatani bunga per musim tanam bunga krisan adalah Rp 5.681.896.

4. Kontribusi pendapatan usahatani bunga krisan terhadap pendapatan total rumah tangga petani sebesar 59,34\%.

\section{DAFTAR PUSTAKA}

Agustian, A. dan N. Ilham. 2008. Analisis Proporsi Pendapatan dan Pengeluaran Rumah Tangga Petani Padi pada Berbagai Ekosistem. Pusat Analisis Sosial Ekonomi dan Kebijakan Pertanian Departemen Pertanian, Bogor.

Barokah, U. S. Suprapti dan S. M. Handayani. 2012. Dampak konversi lahan pertanian terhadap pendapatan rumah tangga petani di Kabupaten Karanganyar. Jurnal Caraka Tani 27 (1) : 93-99.

Badan Pusat Statistik. 2013. Survei Pendapatan Rumah Tangga Usaha Pertanian 2013. Badan Pusat Statistik, Jakarta.

Badan Pusat Statistik Kabupaten Semarang. 2015. Kabupaten Semarang dalam Angka. Badan Pusat Statistik Kabupaten Semarang, Semarang.

Budiarto, K.Y., Sulyo, R. Maaswinkel dan S. Wuryaningsih. 2006. Budidaya Krisan Bunga Potong: Prosedur Sistem Produksi. Jakarta.

Mubyarto. 1991. Pengantar Ekonomi Pertanian. BPFE, Yogyakarta.

Nurdiani, N. 2014. Teknik sampling snowball dalam penelitian lapangan. ComTech 5 (2) : $1110-1118$.

Nurmanaf. 2006. Peranan Sektor Pertanian Terhadap Kesempatan dan Pendapatan di Perdesaan Berbasis Lahan Kering. Jurnal SOCA 8 (3) : 318-322.

Patty, Z. 2010. Kontribusi komoditi kopra terhadap pendapatan rumah tangga petani di Kabupaten Halmahera Utara. Jurnal Agroforesti 2 (3) : $212-220$.

Rahim, A. dan R. D. H. Diah. 2008. Ekonomika Pertanian. Penebar Swadaya, Jakarta.

Sugiyono. 2008. Metode Penelitian Kuantitatif Kualitatif dan R\&D. Alfabeta, Bandung.

Sutarto. 2005. Hubungan sosial ekonomi petani dengan tingkat adopsi inovasi teknologi komoditas jagung di Sidoharjo Wonogiri. Agritex 24 (1) : 1 - 12. 
Soekartawi. 2002. Analisis Usahatani. United States Department of Agriculture Universitas Indonesia Press, Jakarta.

Tegegne, F., S. P. Sigh, E. Ekanem, S. Muhammad. 2001. Labour use by smallscale conventional and sustainable farmers in Tennessee. Southern Rural Sociology 17 (17) : 66- 80.

Tjiptono, F. 1999. Strategi Pemasaran. Andi Offset, Yogyakarta. (USDA). 2004. Farm Bill Comment Forum Comment Summary And Background. Farm Bill Forum, United States.

Zainudin, A. 2007. Aplikasi sistem pertanian organik pada budidaya tanaman bunga krisan di Nongkojajar. Jurnal DEDIKASI 4 (1) : 63-72. 